This is the version of the book review accepted for publication in The China Quarterly published by Cambridge University Press https://doi.org/10.1017/S0305741021000357

Accepted version downloaded from SOAS Research Online: http://eprints.soas.ac.uk/35233

Re-use is subject to the publisher's terms and conditions

\title{
The Politics of the Core Leader in China: Culture, Institution, Legitimacy, and Power Xuezhi Guo Cambridge: Cambridge University Press, 2019434 pp. $£ 90.00$ ISBN 978-1-108-48049-9
}

In The Politics of the Core Leader, Xuezhi Guo explains how the politics of the "core" leader has regulated elite interactions within the Chinese Communist Party (CCP) from Mao Zedong to Xi Jinping. His main argument is that $\mathrm{CCP}$ elite politics has an "enduring tendency toward the "core'," or paramount leader, due to three reasons. The first reason is the powerful influence of traditional Chinese political philosophy in defining political legitimacy. He maintains that Confucianism, which desires the top ruler to be a moral sage-king, has amalgamated with Legalism, which views politics as domination and manipulation, into "Legalized Confucianism" to serve as China's de facto ruling ideology since the Han dynasty, resulting in a ruler-centred polity. The second reason concerns the centralized and hierarchical structure of a Leninist party-state, which makes use of the Party chief's supreme status to entrench one-party monopoly. The third reason is the lack of institutionalization of power transition and consolidation, which minimizes constraints for the CCP general secretary to use their term of office as an "opportunity" to work toward "earning" the status of the "core."

Guo's arguments are made on the basis of an in-depth analysis of traditional Chinese political thinking. He parses Confucian and Legalist texts and discusses examples of their application in ancient times and under the CCP. In addition, drawing on detailed biographical analysis and a very extensive literature review, he examines afresh the evolution of gerontocracy or mentor politics of veteran leaders, ideological domination, leadership transition, and political groupings and factions in the CCP from Mao through $\mathrm{Xi}$. The encyclopaedic attention to detail throughout the book is breath-taking. Yet, insofar as the book aims to construct an alternative paradigm of elite politics based on traditional Chinese philosophy, it is more successful at the theoretical level. In the many case studies that document the actual workings of Chinese elite politics in this book, it seems that the effect of traditional Chinese thinking on elite behaviour is more assumed than proven. It is sometimes unclear how his paradigm sheds light onto the process and outcome of elite interactions hitherto unavailable from a clientelist paradigm.

Despite these limitations, the implications of Guo's arguments are profound for understanding Chinese elite politics. First, in contradistinction to the dominant perspective that collective leadership has become the norm of post-Deng Xiaoping China, Guo's premise that a "core" leader is what is sought by China's political system entails that collective leadership is only ever a temporary mechanism when there is no "core" leader - be it due to the Party chief's inability to earn the recognition as the "core" (such as Zhao Ziyang, Hu Yaobang, Jiang Zemin and $\mathrm{Hu}$ Jintao) or, once earned, failure to keep the recognition due to a colossal failure (such as Mao after the Great Leap Forward). In Guo's paradigm, it is only in these situations that Party elites are allowed to step up to share power with the Party chief and in doing so compete with the chief and each other for the "core" status until a "core" can be identified. Guo maintains that using collective leadership as a mechanism for power competition is legitimate because of the Confucian ethics of meritocratic leadership; moreover, insofar as it is not a blatant challenge to the Party chief, which is incompatible to the Confucius admonition of selfinterests, it enables the political system to "self-adjust and self-regulate" as opposed to leaving a power vacuum. 
Second, the "self-adjusting and self-regulating" mechanism between the "core" and elites in Guo's paradigm entails that there will be "cyclical change" between collective leadership and strongman leadership, since each scenario tends to develop into extremes over time. In the case of collective leadership, prolonged competition for the "core" status among elites will result in a weak party with rampant corruption, as was the case under Hu Jintao. By contrast, a strong "core" leader, such as Mao, tends to gravitate toward arbitrary rule. Guo reasons that these extremes would inevitably trigger a survival crisis in the Party, and thus the cyclical change from collective to strongman leadership or vice versa. The argument is significant for exposing the structural causes and limitations for Xi's strongman leadership.

Third, Guo's paradigm demonstrates that factionalism is structurally embedded in CCP elite politics. This suggests that there are serious constraints to Xi's efforts to stamp out factionalism. Guo observes that due to (1) the lack of institutionalized rules governing how to earn the recognition of the "core" or the "core-in-waiting," and (2) the latent competitive dynamics between the Party chief and other Party elites, the bureaucracy and veteran Party leaders, the Party chief must rely on factions to earn and keep the "core" status. Because Party elites in the post-Deng period tend to have ties with multiple factions, even though the Party chief has strong motivations to purge his political enemies to help earn or maintain the "core" status, it is in his interest not to eliminate any faction completely.

This book is a treasure trove for advanced research of Chinese elite politics. Some sections of the book juxtapose Chinese elite politics with that of other communist systems, and contrast Chinese and Western political thoughts. These should be of interest for postgraduate students and scholars of political science.

Olivia Cheung oc9@soas.ac.uk 